\author{
Matt Coler \\ (INCAS ${ }^{3}$ - Assen, the Netherlands) \\ mattcoler@incas3.eu \\ Edwin Banegas Flores \\ (Chief Linguistic Consultant/Muylaq' Aymara \\ Documentation Project)
}

\title{
A descriptive analysis of Castellano loanwords in Muylaq' Aymara ${ }^{1}$
}

\begin{abstract}
This article explores the morphological and semantic adaptation of loanwords from local Andean Spanish (herein "Castellano") attested in Muylaq' Aymara (a variety of Aymara spoken in the Andean highlands of Peru). In many instances, the adoption of loanwords entails semantic changes of one sort of another, be it an expansion of meaning, a restriction, or a different kind of change altogether. Even when the loanword maintains the same core meaning as in Castellano, interesting interpretations abound, as when a loanword changes grammatical category or the plural or grammatical gender is reanalyzed. This article provides an analysis of all such cases and provides illustrative examples from the authors' fieldwork.

KEYWORDS: Semantics; Loanwords; Peruvian Aymara; Castellano; Andean Spanish; Semantic change.

RESUMEN: Este artículo explora la adaptación morfológica y semántica de los préstamos del español regional andino (Castellano) atestiguada en Muylaq' Aymara (una variedad de Aymara hablada en el altiplano andino del Perú). En muchos casos, la adopción de préstamos lingüísticos implica cambios semánticos de un tipo para otra, ya sea una expansión del significado, una restricción o un tipo de cambio total. Incluso en los casos en que el préstamo lingüístico siga manteniendo el mismo básico como en castellano, reinterpretaciones interesantes abundan, como cuando un préstamo lingüístico cambia la categoría gramatical, o el plural o el género gramatical es reanalizado. Así, este artículo explora todos estos casos, presentando ejemplos ilustrativos elicitados directamente en trabajo de campo de los autores.
\end{abstract}

PALABRAS CLAVES: Semántica; Préstamos lingüísticos; Aymara Peruano; Castellano; Español Andino; Cambio semántico.

${ }^{1}$ We would like to thank Willem Adelaar and Leo Wetzels for their comments. We are also grateful for the insightful input of the anonymous reviewers of the Journal LIAMES. All errors are our own. 


\section{INTRODUCTION}

This paper explores loanwords borrowed into a variant of Aymara spoken in the Andean village of Muylaque (hereafter, Muylaq' Aymara), located approximately 3200m above sea level on the Peruvian altiplano in the district of San Cristobal de Calacoa in Mariscal Nieto province, Moquegua. While the overall account of loanword adoption is largely parallel to other varieties of Aymara, this paper does not provide a comparative study of loanword adoption. Although it will soon be discussed in greater detail, it is worth mentioning at the outset that one way in which Muylaq' Aymara is distinct from other documented varieties is in the amount of loanwords (especially in the variety of so-called "cultural borrowings" which may differ across variants). Nonetheless, the inter-variant differences relating to the borrowing of loanwords is largely inconsequential to this analysis as a whole and so no comparative analysis is provided here. All data used in this article comes from a corpus gathered during a number of trips to Muylaque from 2007 to 2009². The corpus largely consists of several hours of myths, stories, and personal accounts narrated by elders and translated and transcribed with bilingual community members.

Before examining the variety of loanwords in this language, it is useful to provide some background that will facilitate the study of loanword adoption. Of primary importance is a definition of loanwords. To that end, it is instructive to revisit the distinction posited by Haugen (1950) who distinguishes between (i) loanwords (words in which the form and meaning are both copied completely into the recipient language); (ii) loanblends (words comprised of both a part copied from the source language as well as a component from the recipient language); and (iii) loanshifts (words for in which the meaning in the recipient language changes under the influence of the source language). Loanshifts can be further subdivided into loan translations or calques (in which a foreign word or phrase is translated morpheme-by-morpheme into the recipient language, e.g. awa-putawu from Castellano agua potable 'potable water') and semantic loans (in which a new, foreign meaning is borrowed and added to a word in the recipient language on the basis between the foreign model and the native word (Haugen 1950). This article is dedicated primarily to the analysis of loanwords as defined in (i); that is Castellano words borrowed into Aymara. We do not adopt a strict interpretation of what it means for the meaning of the a word to copied "completely" into the target language. We therefore consider loanwords any word in Aymara that originates from Castellano and which has an identifiable meaning in the target language. A loanword must further conform the phonetic inventory and syllabic structure of the target language. Although loanwords are borrowed into the language, we avoid the term "borrowed word" because, following Haspelmath (2008), "borrowing" is defined very narrowly by some linguists.

However, it should be noted at the outset that there is no clear metric to use to certify that a given word, originating from Castellano, with an adjusted phonetic and syllabic structure, is truly a loanword in Aymara. The fact is, the usages of words which originate from Castellano could be part of a code-switch, an indication of incomplete acquisition of one of the two languages of the bilingual speaker, or a momentarily lapse by a bilingual speaker (Poplack \& Sankoff 1984). For example, in a limited number of instances, the

${ }^{2}$ This fieldwork was generously funded by the Free University Amsterdam. 


\section{LIAMES 13}

Castellano word pelo 'hair'. was attested as pilu or pelu meaning both 'hair' as well as 'feathers' pelu-pa-naka-k-či-ha-K 'it must be his feathers' (said of rooster feathers seen near the chickens). However, as the usage of this word was not attested with any regularity and as both nik'uta 'hair' and $p^{h} u j u$ 'feather' are used with greater frequency and are considered to be more correct, words like pelu $\sim$ pilu are not considered loanwords in this article.

To ensure consistency in our definition of what consitutes a loanword, we identify four basic types of criteria for the identification of loanwords, following the indication of Poplack \& Sankoff (ibid):

(i) Frequency of use: The more frequently a specific donor-language item is used in the discourse of the recipient language by a variety of speakers, the more reasonable it is to consider it as being a loanword (viz. (Fries \& Pike 1949)).

(ii) Native-language synonym displacement: If a borrowed term has displaced an indigenous term for the same concept, it can be said to have taken over the role of the latter in the lexicon.

(iii) Morphophonemic and/or syntactic integration: When a borrowed term takes on a phonological shape typical to the recipient language, acquires the morphological affixes appropriate to that language, and functions in sentences as a native word, then it can be considered a well-established borrowing (viz. (Haugen 1950), (Fries \& Pike 1949)).

(iv) Acceptability: If native speakers judge a donor-language word to be the appropriate word choice regardless of their awareness of its etymology, the word in question occupies a special place in the recipient lexicon.

Although these criteria have been adopted to employ a greater degree of certainty in determining that a word in question is indeed a loanword, though this is impossible to know for sure. For example, as regards the first criteria, just how frequent must a loanword be used to be sufficient? Likewise, for the fourth criteria, how many native speakers must judge the donor language word to be appropriate (and what, for that matter, is "appropriate")?

Shifting gears now to provide some background on the history of contact between Castellano and Aymara speakers, initial contact between the two were generally dedicated to missionary efforts. The first known description of Aymara is the Doctrina christiana, $y$ catecismo para la instruccion de los Indios, which was published in Lima in 1584 by an anonymous author. Some twenty years later, the Jesuit missionary Ludovico Bertonio and Diego de Torres Rubio published descriptions of Aymara based on the variety spoken in Juli. At the age of 29, just six years after entering the Society of Jesus, Bertonio produced three descriptions of Aymara. The first two, published in Rome in 1603 are entitled Arte breve de la lengua aymara para introducir el Arte grande de la misma lengua and Arte y grammatica muy copiosa de la lengua aymara. Nine years later, Bertonio published a number of books including the Vocabulario de la lengua aymara, making use of the printing press at the Juli 
COLER \& BANEGAS FLORES - A DESCRIPTIVE ANALysis OF CASTELLANO...

mission. This text provides plenty of examples of Castellano words introduced to Aymara, and a few cases of Aymara words re-interpreted for specific purposes (e.g. the translation of ciencia 'science' is given as yatiña, a noun formed from the verb jati- 'know'. Although these Castellano words could not be considered as loanwords at this time (seeing as they were not in widespread use), many of these words were eventually borrowed into Aymara and are attested in religious discourse today. Observe the irregularity with which the Aymara words are given (while in all other examples in this article, Aymara is written in the IPA, in the following example original orthography is preserved). For some words, the Castellano word is transcribed in Aymara with appropriate attention to the differing phonemic inventory and syllable structure - but for other words, this is not done at all. As an illustration of this discrepancy, observe the variation in the loans kruzana 'crucify' and kurusa 'cross' below. In the latter, the complex onset of cruz is eliminated with an epenthetic $/ \mathrm{u} /$ (Aymara disallows word-initial consonant clusters), and the intervocalic $<\mathrm{z}>$, absent in Aymara, is transcribed as its voiceless counterpart. Finally, an epenthetic /a/ is attached to the end of the word in recognition of the fact that all Aymara words are obligatorily underlyingly vowel-final. Not all these changes are made for the former word kruzana. Such variation in transcription and adaptation is attested in many of the loanwords below, all of which were taken from Vocabulario de la lengua Aymara:

$\begin{array}{ll}\text { angela }<\text { angel } & \text { 'angel' } \\ \text { castiga }<\text { castigar } & \text { 'punish' } \\ \text { Castilla }<\text { Castilla } & \text { 'Castile' } \\ \text { diosa }<\text { dios } & \text { 'god' } \\ \text { iklisya }<\text { inglesia } & \text { 'church' } \\ \text { infiernu }<\text { infierno } & \text { 'hell' } \\ \text { Jesucristu }<\text { Jesucristo } & \text { 'Jesus Christ' } \\ \text { kasa }<\text { casar } & \text { 'marry' } \\ \text { kruzana }<\text { crucificar } & \text { 'crucify' } \\ \text { kurusa }<\text { cruz } & \text { 'cross' } \\ \text { testigo }<\text { testigo } & \text { 'witness' }\end{array}$

The influence of missionaries on the language is evident not just in loanwords having to do with religious practices, but also with traditional greetings. The salutation maraptis, in widespread use even today in the area around Muylaque, serves as a good example. This word is derivable from Maria purísima ('purest Mary'). The proper response, simpikaj originated in sin pecado ('without sin'). Despite the fact that Muylaque has not had a priest for several generations, this greeting, unknown in other villages, clearly has been part of the local variant of the language for some time now and is devoid of religious connotation. Speakers interpret this word as a native, traditional Aymara greeting. A similar explanation holds for the word jusulupaj 'thank you', originating from '(Que) Dios se lo pague' '(may) God bless you' (viz. Vasquez' indication that this form is used only amongst the elderly in the Tiwanaku (Hardman 1989), it is in common use amongst all speakers in Muylaque). Other words that illustrate the influence of Colonial (as opposed to modern) Castellano on Aymara are loanwords like asnu from asno 'donkey' (predating burro in modern Castellano) and parla- from parlar 'speak' (predating hablar in modern Castellano).

The remainder of this article is devoted to providing an overview of loanwords in Muylaq' Aymara. Following Myers-Scotton (2002), we adopt a dichotomy between 
cultural borrowings $(\S 1)$ and core borrowings $(\S 2)$. In this paper, the former designate new concepts in Aymara which come from Castellano while the latter are exemplified by cases in which a Castellano loanword is adopted even though a duplicate meaning already exists. In $\S 3$ we discuss some cases in which cultural and core borrowings have undergone a semantic reanalysis and acquired a broader meaning. Finally, in the fourth section we provide some concluding remarks.

Throughout this text, Castellano words are spelled in accordance with the standard spelling conventions common to all varieties of the Spanish language. Aymara words appear in the International Phonetic Alphabet. Castellano loanwords presented in interlinear glosses are italicized. Note that this article is concerned chiefly with semantic adaptation and adoption of Aymara loanwords and does not concern itself with phonological adaptations. For present purposes, it is sufficient to note that as all Aymara roots are obligatorily vowel-final, loanwords that have a consonantal coda must undergo word-final epenthesis, a process that has been and continues to be productive in all varieties today. In cases where the loanword is consonant-final, adaptation requires the addition of a final /a/, the default Aymara vowel (though there are exceptions). General accounts of phonological loanword adaptation for Northern Aymara as provided in Adelaar with Muysken, 2004; Cerrón-Palomino 2001; Hardman et al. 2001; and, for the particular case of Muylaq' Aymara, Coler (under review).

\section{CULTURAL BORROWINGS}

One of the primary motivations for lexical borrowing is to extend the referential potential of a language. The class of words most closely involved with the culture of a language are the content words (adjectives, nouns, verbs). Thus, these words may be borrowed with greater ease than function words (articles, nouns, conjunctions) because the former have a link to cultural content whereas the latter do not (van Hout \& Muysken 1994). Typical cultural borrowings include words for government and rank (alkati < alcalde 'mayor', kawaরiru < caballero 'gentleman', rihirura < regidor 'alderman', wuwirnu < gobierno 'government') and religious terms (inlisa $\sim$ inwisa $\sim$ inklisa $<$ inglesia 'church', jawlu < diablo 'devil', tijusa < dios 'god'). Other cultural borrowings include "flora and fauna" absent from the Aymara world prior to contact with Europeans.

Flora

$\begin{array}{ll}\text { alha }<\text { alfalfa } & \text { 'alfalfa' } \\ \text { arus } a<\text { arroz } & \text { 'rice' } \\ \text { kalawi }<\text { clavel } & \text { 'carnation' } \\ \text { tiruwu }<\text { trigo } & \text { 'wheat' }\end{array}$

\section{$\underline{\text { Fauna }}$}

$$
\begin{array}{ll}
\text { asnu }<\text { asno } & \text { 'donkey' } \\
\text { čiwata }<\text { chivata } & \text { 'goat' } \\
\text { kawa } u<\text { caballo } & \text { 'horse' } \\
\text { uwiha }<\text { oveja } & \text { 'sheep' } \\
\text { waka }<\text { vaca } & \text { 'bovine' }
\end{array}
$$

It is noteworthy that the reference animal indicated by some of the translations above do not always precisely match. For example, the word waka (< vaca) signifies 'bovine' in Muylaq' Aymara, rather than 'cow', as this word is used to refer to bulls, calves, and any sort of ox. Similarly, čiwata (< chivata) is used as a generic term for all goats, not just doelings. 
COLER \& BANEGAS FLORES - A DESCRIPTIVE ANALysis OF CASTELLANO...

Still other cultural borrowings include artifacts introduced to the local culture, as below:

$\begin{array}{ll}\text { asukara }<\text { azucar } & \text { 'sugar' } \\ \text { kansira }<\text { cancer } & \text { 'cancer' } \\ \text { kurwata }<\text { corbata } & \text { 'necktie' } \\ \text { lipra }<\text { libra } & \text { 'currency unit' } \\ \text { Kawi }<\text { llave } & \text { 'key' } \\ \text { pantiwuna }<\text { panteón } & \text { 'graveyard' } \\ p^{h} \text { iriju }<\text { vidrio } & \text { 'glass' } \\ p^{h} \text { usp } p^{h} u r u<\text { fósforo } & \text { 'match' } \\ p^{h} \text { utu }<\text { foto } & \text { 'photograph' } \\ \text { walti }<\text { balde } & \text { 'bucket' } \\ \text { wila }<\text { vela } & \text { 'candle' } \\ \text { wirju } \sim p^{h} \text { iriju }<\text { vidrio } & \text { 'glass' }\end{array}$

It is interesting to take a closer look at the Aymara borrowed word Kawi from the Castellano llave 'key'. This word may also convey a verbal meaning 'shut, close firmly' or 'lock', as in the following utterance where it is attached with the derivational verbal reverser suffix -гpaja: Kawi-rpaja-m 'leave it open'. In the sentence below, the derivational distancer verbal suffix -muku attaches to the root Kawi- 'lock', expressing reverser semantics:

\begin{tabular}{lll} 
mamala-xa-x & ut & \multicolumn{1}{c}{ hawi-muku-wa- $\sin ^{3}$} \\
mom-1POSS-TOP & house.ACC & lock-DIST-BFR-SUBR \\
'My mom, leaving the house unlocked...' &
\end{tabular}

It is interesting to consider utterances of cultural borrowings which exhibit some kind of variation in their realization. For example, the pair disajunu-naka and disajuna-naka are both borrowed into Muylaq' Aymara as 'breakfast foods' (< desayuno 'breakfast'). The reason for the variation in final vowel of the source word is unclear -- after all there is no biological sex involved in this word.

$$
\begin{array}{lll}
\text { kuna } & \text { disajuna-nak(a)-s(a) } & \text { ap-ha-r-t'a-wh-č } \\
\text { what } & \text { breakfast-PL-AD } & \text { take-atop-MLT-M-BFR-CNJ.3 >3SIM } \\
\text { 'Also she surely took up some breakfast' }
\end{array}
$$

Aside from cultural borrowings of the sort described so far, there are also cultural borrowings that originate not in the introduction of foreign animals, plants, or artifacts but in social conventions. The traditional greeting/response of maraptis/simpikaj described

${ }^{3}$ Abbreviations used in the interlinear glosses in this article follow:

$\begin{array}{llll}\text { ACC } & \text { accusative } & \text { GEN } & \text { genitive } \\ \text { AD } & \text { additive } & \text { IMP } & \text { imperative } \\ \text { AG } & \text { agentive nominalizer } & \text { IW } & \text { inward } \\ \text { ALL } & \text { allative } & \text { LOC } & \text { locative } \\ \text { ANMZ } & \text { action nominalizer } & \text { M } & \text { momentaneous } \\ \text { BEN } & \text { benefactive case declension } & \text { MLT } & \text { multiplier }\end{array}$




\section{LIAMES 13}

in the introduction is one such example. Another is apparent in the reinterpretation of the Castellano word mira 'look', which has come to mean 'please' in Muylaq' Aymara. An illustrative pair of positive and negative utterances with this word follow.

$$
\begin{array}{lll}
\text { mira }, \quad \text { aka law } & \text { aj-su-rap-ita } \\
\text { please this stick.ACC } & \text { take.cylindrical.object-OW-BN-2>1IMP } \\
\text { 'Please take this stick for me' } &
\end{array}
$$

$$
\begin{array}{lll}
\text { mira } & \text { han } & \text { wij-kat-ista-ti } \\
\text { please no } & \text { light.fire-MA-2>1SIM-NEG/IR } \\
\text { 'Please don't light me on fire' }
\end{array}
$$

\section{CORE BORROWINGS}

A Castellano loanword that is adopted despite the fact that a word for that concept already exists in Aymara is considered a core borrowing (Myers-Scotton 2006). Preliminary observations by the authors indicate that core borrowings are more common in Muylaq' Aymara than in other documented varieties. As an illustration, observe how every root in the sentence below is a core borrowing:

$$
\begin{aligned}
& \text { solo riata-ki-w } \\
& \text { only rope-DL-DECL } \\
& \text { 'It is just rope one had to use' }
\end{aligned}
$$

In some cases, the core borrowing and the native Aymara word coexist while in other cases one has replaced the other. Examples of the former are provided presently.

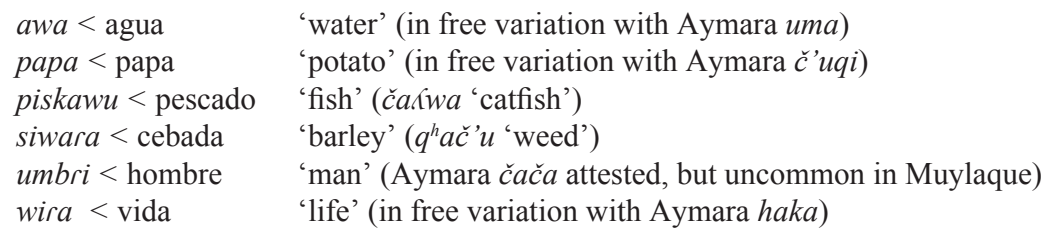

$\begin{array}{llll}\text { BFR } & \text { buffer } & \text { NEG/IR } & \text { negative/interrogative } \\ \text { BN } & \text { beneficiary } & \text { OW } & \text { outward } \\ \text { CAUS } & \text { causative } & \text { PL } & \text { plural } \\ \text { CIS } & \text { cislocative } & \text { PROG } & \text { progressive } \\ \text { CNJ } & \text { conjectural } & \text { PRP } & \text { propogative } \\ \text { COM } & \text { comitative/instrumental case declension } & \text { RE } & \text { resultative } \\ \text { CP } & \text { comparative } & \text { REC } & \text { recent past } \\ \text { CPL } & \text { completive } & \text { REFL } & \text { reflexive } \\ \text { DECL } & \text { declarative } & \text { REM } & \text { remote past } \\ \text { DIST } & \text { distancer } & \text { RV } & \text { reverser } \\ \text { DL } & \text { delimitative } & \text { SIM } & \text { simple tense } \\ \text { DW } & \text { downward } & \text { SUBR } & \text { subordinator } \\ \text { EM } & \text { emphatic } & \text { TOP } & \text { topicalizer } \\ \text { FUT } & \text { future tense } & \text { UW } & \text { upward }\end{array}$


COLER \& BANEGAS FLORES - A DESCRIPTIVE ANALYSIS OF CASTELLANO...

While in most of these examples, the borrowed form and the native one coexist in variation, there are some exceptions. The word čaরwa 'catfish', above, is a suitable illustration. Whereas in other documented varieties of Aymara this word means 'fish', in Muylaq' Aymara it has come to mean a specific kind of fish and the borrowed word piskawu signifies the generic category. This can be considered as a kind of loanshift insofar as the meaning of $\check{c} a \hat{K} w a$ was modified as a result of the introduction of the word piskawu. This is parallel with the situation for siwara (< cebada 'barley') which is $q^{h} a c ̌$ ' $u$ in other varieties. However, in Muylaq' Aymara, $q^{h} a c ̌$ ' $u$ is a general word for 'weed'.

Instances in which a core borrowing has replaced an Aymara word can be further subdivided into examples in which that replacement has occurred in all varieties of Aymara (e.g. awasa < habas 'beans') and examples in which that replacement has occurred only in Muylaq' Aymara:

$$
\begin{array}{ll}
\text { alwuruna }<\text { algodón } & \text { 'cotton' (Aymara } q^{h} \text { iya unattested in Muylaque) } \\
\text { kumuna }<\text { comunidad } & \text { 'community' (Aymara ayllu unattested in Muylaque) } \\
\text { lawruna }<\text { ladrón } & \text { 'thief' (Aymara lunt } \text { ata unattested in Muylaque) } \\
\text { pirimiru }<\text { primero } & \text { 'first' (Aymara najriri unattested in Muylaque) } \\
\text { punawu }<\text { puñado } & \text { 'handful' (Aymara hač'i unattested in Muylaque) } \\
\text { wisina }<\text { vecina } & \text { 'neighbor' (Aymara hak'ankiri unattested in Muylaque) }
\end{array}
$$

For illustrative purposes, examples of the usages of some of these words follow. In the first utterance, the borrowed word wisina 'neighbor' is modified by warmi. Although this may seem to illustrate that unlike the gender implicit to Castellano vecina 'neighbor.female', the Aymara loanword does not specify the gender of the referent. This is, however, not completely true. Most speakers would use the word wisinu for a male neighbor. However, there is indeed some ambiguity as /a/ is the default vowel attached to consonant-final borrowed words. Hence, some speakers still specify the gender of the referent with words like warmi 'woman'. The second sentence illustrates the word lawruna 'thief' declined into the comparative case and affixed with the additive suffix:

$$
\begin{array}{lll}
\text { warmi-x } & \text { wisina-x } & \text { mist-ta-rak-č-i-x } \\
\text { woman-TOP } & \text { neighbor-TOP } & \text { leave-UW-AD-CNJ-3SIM-TOP } \\
\text { 'The female neighbor must've left again' }
\end{array}
$$

$$
\begin{aligned}
& \text { lawruna-mp-rak ut } \\
& \text { thief-COM-AD house.ACC } \\
& \text { q'ipi-qa-ya-s.ka-sma } \\
& \text { carry.in.cloth-DW-CAUS-PROG-2>3PRES.CF } \\
& \text { 'Be careful that you do not let the thief rob the house' }
\end{aligned}
$$

The Castellano word bóveda meaning 'crypt' or 'vault', has been borrowed into Muylaq' Aymara as wuwi. This word has come to acquire a very specific meaning, referring as it does to particular set of caves under a sacred rock where the disinterred dead are again laid to rest: 


\begin{tabular}{|c|c|c|c|}
\hline & & $\triangle E S 13$ & \\
\hline & $\underline{w u w i}$ & p’ija-nak & $p^{h} i s k u$-ri-s \\
\hline
\end{tabular}

'They even used to clean those burial-caverns'

While the core borrowings discussed so far are nominal, there are also verbs that are core borrowings, like the root parla- 'speak' (native aru- 'speak' only appears in a limited number of fossilized constructions, as with the sustainer, as $-\check{c}$ ' $u k i$ ' $y e l l$ '). Another example is the nominal/verbal root wirsu(-) which comes from Castellano verso 'verse' (from Christian Scripture). This word can be interpreted either as the verb 'sing' or the noun 'song' - though Aymara has its own words, haj $i \dot{i}$ - and q'uču, respectively (cf. Kawi(-) 'key', 'close firmly, lock').

$$
\begin{array}{lll}
\text { wirsu-tata-whw-i-x } & \text { pasku } & \text { wirs } \\
\text { sing-PRP-BFR-3SIM-TOP } & \text { Easter } & \text { song.ACC } \\
\text { 'She started to sing an Easter song' } &
\end{array}
$$

The same sort of analysis can also account for the meaning expressed with the loanword wanu from baño meaning 'bath, bathroom' in Castellano. This word has likewise been reanalyzed to convey a verbal meaning in Muylaq' Aymara: 'bathe' (viz. Castellano bañarse). Moreover, siKa 'seat' (< silla) can also be used as a verb meaning 'sit' (the native noun qunu-ña 'seat' is understood with a more specific meaning: 'sit to make oneself comfortable'). The following two sentences illustrate verbal usages of wanu- and siKa-:

$\begin{array}{llll}\text { hani-w } & \text { q'alt } & \text { pača-x } & \text { wanu-si-hata-t } \\ \text { no-DECL } & \text { dawn time-TOP } & \text { bathe-REFL-2FUT-NEG/IR } \\ \text { 'You will not bathe yourself early tomorrow' } & \end{array}$
$\begin{array}{lll}\text { kawa } u \text {-n-x } & \text { lihu } & \text { si } \text {-hata-t } \\ \text { horse-LOC-TOP } & \text { all } & \text { sit-above-RE }\end{array}$
sara-wh-č-i-x
'Nicely seated on horseback, he must've gone'
go-CPL-CNJ-3SIM-TOP

As the infinitive form of Castellano verbs always ends in a vowel + rhotic, the final $/ \mathrm{r} /$ is ignored in adaptation to Aymara. The Aymara loanword is based on the Castellano verb without the inflective -r ending. A few examples follow:

$\begin{array}{lll}\begin{array}{l}\text { Castellano } \\ \text { avisa- }\end{array} & \begin{array}{l}\text { Aymara } \\ \text { awisa- }\end{array} & \begin{array}{l}\text { Gloss } \\ \text { burla- }\end{array} \\ \text { wurla- } & \text { 'tell' } \\ \text { castiga- } & \text { kastija- } & \text { 'putwit' } \\ \text { copea- } & \text { kupija- } & \text { 'toast' } \\ \text { engaña- } & \text { inkana- } & \text { 'deceive' } \\ \text { frei- } & p^{h} \text { iri- } & \text { 'fry' } \\ \text { manda - } & \text { mant } & \text { 'order' } \\ \text { paga- } & \text { paja- } & \text { 'pay' } \\ \text { queda- } & \text { kida- } & \text { 'stay' }\end{array}$


COLER \& BANEGAS FLORES - A DESCRIPTIVE ANALYSIS OF CASTELLANO...

The bare form of an Aymara verb only exists metalinguistically. Verbs borrowed from Castellano, just like those native to Aymara, never appear bare. Examples of suffixation with verbs borrowed from Castellano are provided in the following utterances, each of which is suffixed with a different set of verbal suffixes:

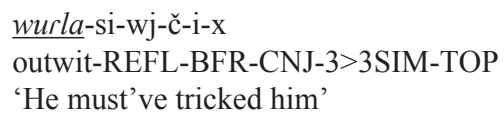

$\begin{array}{lll}\text { hiča-x } & \text { KuqaKa-naka-ru-x } & \text { mant }^{h} a \text {-hwa-p } \\ \text { now-TOP } & \text { boy-PL-ALL-TOP } & \text { order-BFR-AD.3>3SIM }\end{array}$

'Now they ordered the boys around, too'

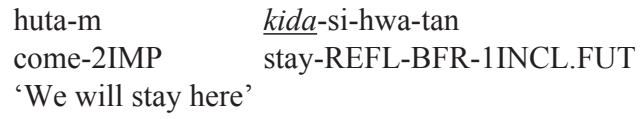

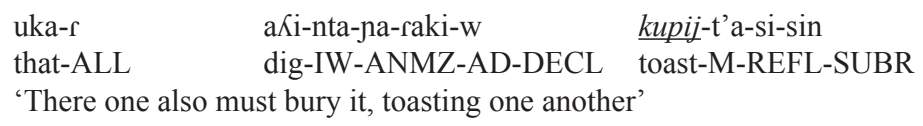

Some verbal core borrowings have a more complex origin. For instance, the loanword pustu from Castellano puesto (the past participle of poner 'put') never occurs without the factive root verbalizer $-\check{c} a$ suffixed. The resultant word, pustu- $\check{c} a-$, means 'prepare'. This verb appears in the sentence below. Incidentally, observe how every root in this sentence is a loanword.

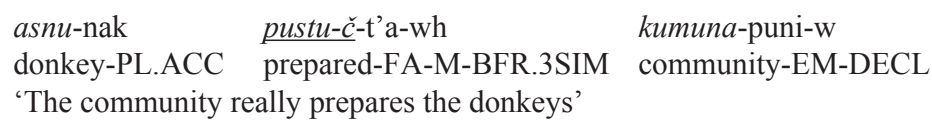

Some loanwords change categories when they are borrowed into Aymara. As an illustration of this tendency, consider the Muylaq' Aymara loanword $p^{h} i s k u$-, which is a verb in the target language, but derives from an adjective in Castellano (fresco 'fresh'). The impetus for this change likely stems from the fact that Aymara adjectives are nominal - that is, there is no category of adjectives as such in this language. The two examples below illustrate the interpretation of $p^{h} i s k u$ - as a verb. In the first, this root is affixed with the causative $-j a$, whereas in the second it is attached with the cislocative suffix.

$$
\begin{array}{lll}
\begin{array}{l}
\text { inglis } \\
\text { church.ACC }
\end{array} & p^{h} \text { isku-ja-s.ka-p }{ }^{\mathrm{h}} \text {-itan } & \text { ahinti-s } \\
\text { clean-CAUS-PROG-PL-3>1REC } & \text { agent-AD } \\
\text { 'And the agent made us clean the church' } &
\end{array}
$$

$$
\begin{aligned}
& \text { pantiwun } \\
& \text { cemetery.ACC } \\
& \text { 'You all will go clean the cemetery' }
\end{aligned}
$$




\section{LIAMES 13}

Some core borrowings may involve a less obvious meanings of a Castellano loan. It is thus relevant to consider the phenomenon of polysemy. Take for example the loanword wulpi from Castellano golpe. This word has come to mean 'instance', e.g. ma wulpi 'once', pa wulpi 'twice' (ma kuti 'once' in other varieties, is unintellible in Muylaq' Aymara).

$$
\begin{array}{lllll}
\mathrm{k}^{\mathrm{h}} \mathrm{a} & \text { parki-ru-x } & \text { pa } & \text { wulp } & \text { jiw-t } \\
\text { yonder } & \text { acclivity-ALL-TOP } & \text { two } & \text { time } & \text { die-1SIM } \\
\text { 'On yonder mountainside, I fainted twice' } & &
\end{array}
$$

A similar account also holds for Castellano adjectives like feo, which, typically means 'ugly' but which can also express the notion of 'bad' or 'wicked', as in the sentence below where it has been adopted as the noun $p^{h} i j u$ (cf. the Castellano adjective fresco which was adopted as the verb $p^{h} i s k u$-):

$$
\begin{aligned}
& \text { uka usu-x wali } p^{h} i j u-v \text {-tajna-w } \\
& \text { that bear-TOP very bad-COP.VBZ-3REM-DECL }
\end{aligned}
$$

Similarly, the loanword awri from Castellano abrir is not typically attested as a loanword meaning 'open' (in the sense of 'open a door'). Instead, it is translated as 'disenchant something/someone spellbound' (usually, as below, said of an enchanted mountain). This corresponds to the meaning expressed by the native root hist' $a$ - 'close' suffixed with the verbal derivational reverser $-r a$, as in hist' $a-r a$ - 'open' in the second sentence below:

$$
\begin{array}{llll}
l u k & \text { aka } & \mathrm{qu} \kappa & \text { awri }-\mathrm{p}^{\mathrm{h}} \mathrm{a}-\mathrm{m} \\
\text { fast } & \text { this } & \text { mountain.ACC } & \text { open-PL-2IMP }
\end{array}
$$

'Disenchant these mountains right now!'

$$
\begin{aligned}
& \text { uka jawlu-naka-x uka quK } \quad \frac{\text { hist'a-ra-hwa-p }}{\text { ha } a-t a j n a-w} \\
& \text { that devil-PL-TOP that mountain.ACC close-RV-BFR-PL-3>3REM-DECL } \\
& \text { 'Those devils disenchanted that mountain' }
\end{aligned}
$$

\section{REANALYSIS OF LOANWORDS}

In a handful of cases, cultural and core borrowings have undergone reanalysis and consequently acquired a broader meaning. This is evident not only in the frequency with which a borrowed word acquires both a nominal and verbal interpretation, but also in other types of semantic expansion. For example, the borrowed word musiku ( $<$ músico) 'musician' has come to mean 'band' as well as 'music':

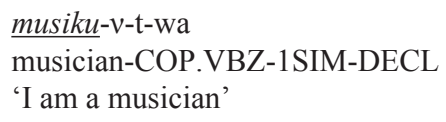


COLER \& BANEGAS FLORES - A DESCRIPTIVE ANALYSIS OF CASTELLANO...

$\begin{aligned} & \text { musiku-mp uka wila-mpi-w } \\ & \text { band-COM that candle-COM-DECL }\end{aligned}$
sar-t'a-wh-tan-x
go-M-BFR-1INCL.SIM-TOP
'With the band with that candle we go to the church'

Another more complex case is the Aymara word is luku, which seems to have resulted from a combination of loco 'crazy' and luego 'at once, quickly' (as Aymara lacks the phoneme $/ \mathrm{g} /$, when loanwords with this segment are adopted, it is typically replaced with $/ \mathrm{k} /$, thus resulting in greater similarity with loco). While luku can indeed mean 'be crazy', as in luku-spha-w 'he must be crazy', it more often connotes something done speedily and with urgency:

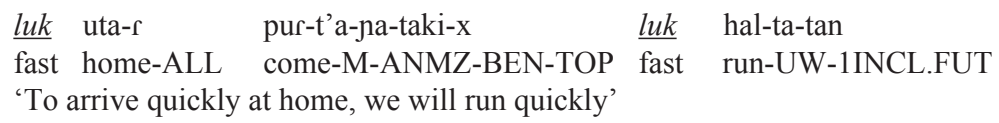

In a few instances, Castellano loanwords pluralized with the native Castellano $-s$ were interpreted as singular in Aymara. Thus, these words are pluralized with the Aymara nominal pluralizer -naka; e.g. kusasa (<cosas 'things') and wankasa $(<$ mangas 'sleeves').

$$
\begin{aligned}
& \text { wali } \begin{array}{l}
\text { kusa.sa-naka-n } \\
\text { good thing-PL-ATT }
\end{array} \\
& \text { '(they have) good things' }
\end{aligned}
$$

\section{CONCLUSION}

This article has provided a preliminary semantic account of Aymara words borrowed from Castellano (loanwords in the sense of Haugen, 1950). According to this analysis, the loanwords are shown to fit neatly into Haspelmath's (2008) division between cultural and core borrowings. In some instances, a loanword in reanalyzed and consequently undergoes a semantic change. A few representative examples illustrate how loanwords are borrowed as lexical concepts, devoid of any grammatical category and then treated as verbs or nouns -- or, in a handful of cases, both: e.g. wirsu(-) 'sing', 'song', llawi(-) 'open', 'key', silla(-) 'sit', 'seat'.

This account focused mainly on the adoption of loanwords and so did not explore in much detail loanblends or loanshifts, like calques, as in tula-wira $(<$ toda vida 'entire life'), below. Nor did it explore phonological and syllabic adaptations, which, interesting though they may be, must be the topic of a future study.

$$
\begin{aligned}
& \text { ak } \begin{array}{l}
\text { tula-wira-s } \\
\text { this lifetime-AD }
\end{array} \text { last-3>2IMP-TOP } \\
& \text { 'May this last even an entire lifetime' }
\end{aligned}
$$




\section{LIAMES 13}

It is our hope that this article serves as a springboard for future studies on loanwords in (and among) Andean languages that will ultimately shed light on some of the constraints effecting the paths of language change.

\section{BIBLIOGRAPHIC REFERENCES}

ADELAAR, Willem F. H.; MUYSKEN, Pieter (2004). The languages of the Andes. Cambridge: Cambridge University Press.

CERRÓN-PALOMINO, Rodolfo (2000). Lingüística aimara. Lima: Centro de Estudios Regionales Andinos.

COLER, Matt (under review). A grammatical description of Muylaq' Aymara.

FRIES, Charles. C.; PIKE, Kenneth L. (1949). Coexistent phonemic systems. Language 25(1): 29-50.

HARDMAN, Martha J.; VÁSQUEZ, Juan; YAPITA, Juan de Dios, et al. (2001). Aymara: compendio de estructura fonológica y gramatical. La Paz: Instituto de Lengua y Cultura Aymara. Online version: http:// www.ilcanet.org/publicaciones/pdf_compendio.html. June 19, 2009.

HARDMAN, Martha (ed.) (1989). The Aymara language in its social and cultural context. Gainesville: University Press of Florida.

HASPELMATH, Martin (2008). Loanword typology: Steps toward a systematic cross-linguistic study of lexical borrowability. In Thomas Stolz; Dik Bakker; Rosa Salas Palomo (eds.) 2008. Aspects of Language contact. New Theoretical, Methodological and Empirical Findings with Special Focus on Romancisation Processes, pp. 43-60. Berlin: Mouton de Gruyter.

HAUGEN, Einar (1950). The analysis of linguistic borrowing. Language 26(2): 210 -231.

MYERS-SCOTTON, Carol (2002). Language contact: Bilingual encounters and grammatical outcomes. Oxford: Oxford University Press.

POPLACK, Shana; SANKOFF, David (1984). Borrowing: the synchrony of integration. Linguistics 22(1): 99-136.

VAN HOUT, Roeland; MUYSKEN, Pieter (1994). Modeling lexical borrowability. Language variation and change 6(1): 39-62.

Recebido: 3/1/2013

Versão revista: 9/4/2013

Aceito: 21/6/2013. 